\title{
Melon, melocoton o flan
}

\section{J. M. Main}

What was infatuation, love. Paper dolls, a pastime, faraway? Absolutely, I refuse, she said again, I refuse, I refuse! Mrs. Bernadine looked blandly into his bland face, he happened not to be looking at her, her husband's between them, and said again, I refuse. Simply, it was not enough to be at a distance from the usual and yet of course it was with her having nothing to say to him that man Arthur except Christ in a bed. In bed. In bed! For them, oh not her, it was on the circuit all a merry tra la la merry-go-round. This bed. That bed. Wild people, they thought nothing of it. Why not, they said, laughing. Something to do, they said. And so available. The rooms afternoons from two until four o'clock for example were each shuttered, remote. He and she had only to turn away from him, her husband Frederick who was busy anyway, Mr. Domner being Mr. Domner and besieged, and lock themselves in for those several hours. But first and how idiotic! she must finally if she chose look across the dining table, merely look directly at him, mustn't she. At the same time of course. As it was for days now-when had it started, he looked, stared at her. It was ridiculous. Embarrassing. Further she knew, certainly she knew, that he did not think she was pretty, that he thought of her as bony, aging, and yet without question as an inevitable recipient for him. At siesta or anytime. As for her, he was too young: she could see day after day these several weeks not only what he was but what his life was apt to be, all too lean. Who wanted to be even a trivial part of any of what he was. Mrs. Bernadine put down her fork. For herself sitting there tightly, aware of his bland eyes on her, the fact of it was she too thought of herself as his recipient. In dusky daylight for him at siesta. Or anytime. In his hotel room or hers, it didn't matter which: maybe his room: not that it faced on the cove although it did but because Frederick puffing on his pipe had never been in it.

But of course Frederick had. Of course, and when it occurred to her it surprisingly made no difference. Mrs. Bernadine acknowledged it. As they said, why not. With them and their crowd-she was out of it, it wasn't worth remarking. Arthur had been working for Frederick both on the circuits and at the home 
studios and so what: so he had buried his young face in Frederick's old crotch, who hadn't, Frederick being Frederick and wonderful. Everybody loved Frederick. Almost.

"Well then, please pass the butter," said old Frederick between them. So she passed it to him. It was oleo.

"Mrs. Bernadine, don't touch me," said Arthur, his face bland, now yellow, green, red, purple, in the station neon as they waited, the depot full of sounds of trains and people.

"Touch you. My heavens, I'm not even near you."

"You are. Yes you are. You somehow keep moving closer."

"You must be crazy. I'm looking in this shop window. Look at the leather gloves. Aren't they lovely. You followed me."

"The gloves? What gloves?"

"The gloves, those gloves, what else. That's what I'm talking about. They're a buy here, gloves like that. They were more expensive in Zaragosa, can you imagine."

"Can I imagine? Imagine what, Mrs. Bernadine?"

"Arthur, I am talking about gloves."

"Gloves. We've hardly spoken alone, always chitchat with the others, but God, gloves. Mrs. Bernadine, you are too much for me. Just being around you. You're not even pretty."

"Pretty. Why, Arthur, I know that."

"And you're forty or more. At least."

"More than forty. You're right."

"I know. I know, I could tell. And you're talking about gloves? Those funky gloves? Those gloves are driving gloves so your hands don't slip on the wheel."

"I know that. Arthur, I really think Frederick is taking too long. You'll miss the train. Did Frederick know where the telephones are? Is Mr. Domner settled? The train will go. Look. We're reflected in the shop windows. We're multicolored all at once aren't we."

"Multi-colored. Mrs. Bernadine. Jesus. What crap. I don't know what to say to you. I can't say anything to you. Why don't you look at me? No, don't look at me. I mean, let's keep on looking at those fucking gloves."

"That's all I am doing."

"Well yes that's exactly right. You are."

"The train goes in seven minutes."

"The Halsteads got the accommodations out in Neuilly-St.-James again. That's where we'll be."

"Well, Arthur, you'll miss Spain I'd guess. It's so exotic a country wouldn't you say."

"Me? Spain? Me say Spain was exotic. Oh I'd never say anything like that. Mrs. Bernadine, I'd never even think it."

"Oh."

"Mrs. Bernadine, you don't make sense. It's not that I'm all that young." 
"You don't have to be young to think that Spain's exotic."

"I don't mean that. I mean, who's talking about Spain. I would do anything to be older. That's the situation isn't it."

"No."

"What do you mean, no."

"I mean, well. Look at that rhinestone comb."

"Christ, rhinestones! I'm not some kid! I've worked! I had to go to war. Is it you want me to buy you something, gloves, a comb. Frederick can buy you anything. I'm down to 600 pesetas."

"You must be crazy to think I want you to buy ..."

"Mrs. Bernadine. You're coming closer. You've never touched me. Not once. Do you know that. Don't touch me. I mean if you touch me, so much as a finger, I think I'll pass out."

"Pass out?"

"Yes, I mean it, right here. I've had my go arounds, never fear, you can count on that. But this, I don't know. This is too much for me. Besides you've probably had this experience before. Lots of times. Men working for your husband and all."

"No. I have not."

"What do you mean, no, you have not."

"What do I mean, no, I have not? I mean, no, I have not. Never. It's different for you, for everybody, for Frederick. I know that. For me this is totally-bewildering. I could spit!"

"The words you use, such crummy words. You're putting me on."

"I'm not. I don't even want to talk to you. Do you understand that."

"You look like a young girl to me."

"Oh no I don't. I don't look like a young girl to anybody."

"Yes you do. It's your voice, the way you move. What Frederick sees in you, always saw in you, I see too. Something's fucked up. It is. It is. I think I'll break this shop window."

"I’m not pretty. I never was."

"I know that."

"Well it's the truth."

"Look. Right here in a public building and I cannot keep my goddamned eyes off you, Mrs. Bernadine. Christ, if you're so smartass why don't you . . ."

"Arthur, if I were a young girl I ..."

"Who wants a young girl."

"You do."

"Mrs. Bernadine, I'll be a year older when you get to Paris."

"Stupid! I'll be older too."

"So! So! Why make so much of it! Christ, I've sat at mealtimes with you for weeks, all those lousy courses, and Frederick and everybody and you never even looked at me. Not once."

"This is ridiculous. What a conversation."

"And why not this conversation? I mean if I'm just another person at the table you could have at least looked at me." 
"No."

"No? You might be older but ..."

"Not might, am-anyway, I know about you and Frederick. It's not that I care. Honestly, you people."

"Frederick? Oh well, that's just fun and games."

"Fun and games!"

"Yes. Fun-and-games. And why not. What's so special. It's nothing. Look-it isn't like you've got the only one in the world you know. I mean, who are you!"

"I don't play games. I don't even play bridge."

"Bridge. Bridge? What's bridge. Who's talking about bridge."

"There's Frederick. Why did you, you know, with Frederick."

"I don't know, Mrs. Bernadine. If I did, it's like I said, why not."

"Oh."

"Listen, I tell you, you and I we'd be fine with each other. It's right for us. I know it. Even if only once in awhile. Isn't that so. I'll be back here for a week or more after the first...."

"The train's going to leave any minute. Say hello to France for me. There are the Rileys and the Halsteads. Everybody."

"I see them. I wish you'd answer me. I wish you'd say something worth saying."

Frederick coming over had a plastic sack filled with candy bars. He pushed it into Arthur's hands. "Oh. Well now. Candy bars," said Arthur. "Did you talk to Paris, Frederick?" Arthur asked. "I have the tickets. We're in," Arthur said, "Compartments 1 and 3, 4, 7, 8 and 9." Looking up into one of the windows they could see Mr. Domner getting settled in his private compartment, flustered, dressed in gray, while Miss Penn with her big spectacles was already pouring coffee for him from the thermos. "Well everybody's set, Frederick," said Arthur. "Goodbye. I'll see you down here next month. I'll send the tapes, all the notices."

They shook hands.

Arthur turned. "Goodbye, Mrs. Bernadine," he said.

"Yes. Adiós," she said.

"Your one word of Spanish?" he asked.

"Yes," she answered.

Now with the whole grinning Paris office getting themselves settled, waving, leaning out comically, with old Frederick at her elbow, pipe smoke blowing and the depot shadowy, ochre, with Arthur not moving, he could move, he doesn't, she kisses him, that young man, lightly on the cheek, her hand lightly on his shoulder. For only one fraction of a second does his face turn his mouth towards her mouth, but instantly away. They do now look at one another, their glances bland. This, she thinks, he thinks, is no place to say hello, no place to say goodbye, no place at all. It is too noisy they think looking at each other, too crowded, too foreign.

"So," said Frederick amiably sipping his brandy, signaling the waiter for more coffee, Frederick such an imposing man, his beard as red and graying as his hair, the firelight every which way, "it turns out he's a prissy little cock- 
sucker." He took another sip. "That is, not literally. His wife's quite nice."

"Oh."

"That wife of his," he went on, Frederick seldom talked about people but he was giving himself over to it for some reason, "is what he's all about. Without her I wouldn't have him in the office."

"Well Nell's pleasant."

"Is that her name? I 'Mrs.' her to death all the time, like talking grown-up talk to a child. She still has shitty looking milk teeth. Do you know, kid teeth. And," he paused, brandy glass mid-air, "she is anyone can see bossy and obedient in that odd way some women have. She hates traveling as much as you do."

"Oh."

"But she's obedient, like I said. Not meek, mind you. She tells him straight off, polite as Mom. It's all her. She'll ask him for French 'parfum' at Christmas just because they're in Paris then."

"Well."

"Actually without her he'd be absolutely someone else. He's from Denver and ..."

"From Denver?"

"Oh yes, and from money. The family's got money. But given another so-called "helpmeet," Frederick snickered, sometimes he snickered, always incongruous with his good looks, "he'd nevertheless be into the till I can assure you. Or," he laughed out loud, "he'd be home on sick leave pay to the minute of the year's allowance. As it is she has him in a clean shirt on the hour and even made him quit smoking. A real company man."

"He smokes? I didn't know he smoked. In fact I'd be glad if you'd stop that pipe, Fred."

"He quit smoking I'd say several seasons or more ago. Took medication."

"He hasn't been with us several seasons."

"Of course he has. Here. There. More, you know that."

"It doesn't seem he's been on staff that long."

"He's been with me going on four seasons. Don't you remember in Milano and ..."

"Oh, he has not. Who're you talking about anyway?"

"Why Billy Halstead. Who else."

"Billy? I didn't think you were talking about Billy."

"Who else would I be talking about. Billy Halstead and his wife Nell. Little Mrs. Milk Teeth Halstead. Nell, you even said her name yourself."

"But that's not Nell. That's Estelle. Nell's in Paris."

"Nell. Estelle. Seashell. What's the difference. I never did know her first name. Whatever her name is she looks like a real Mary Mouse to me. Billy. You know," he finished his brandy and half of hers, "good old Billy. Skinny Billy Willy and Mary Mouse of the Milk Teeth off to Paris in Compartment something or other with all the others, thank God." He looked towards the fire, then at her. "I'm glad to be on holiday again after all that," he said. "I'm glad you 
came along this trip. Come on," he said, "what do you say we go on upstairs and have a little jiggle-jaggle with some Inca wine."

"There's nothing like a little jiggle-jaggle with some Inca wine is there, Frederick?" she said.

"Absolutely nothing, Tootsie. We can jiggle-jiggle-jaggle."

"That's right."

"All night long. I'll really get you kid. Once for all."

"Like always."

“That's right. And I know just where to get you don't I?"

"Where."

"You want me to say it out?"

"Of course. Sweetheart."

Mrs. Bernadine tipped her head back, her tongue at her teeth, but Frederick only leaned over touching her plain face with his hand, his thumb just there at her jaw. Sitting there-an immense red-headed man, tan, bearded, leaning forward, they were silhouettes in firelight in leather chairs at a restaurant table, she stylish and bony, just beginning to age. He started to say something and stopped. Then took his hand away. He settled back. They sat there. He sighed. He looked about him as if suddenly restless. The restaurant, the hotel, its lobby, the stairway, were flamboyant in orange and white, bright yellows, gold.

"It's nice here isn't it," he said then finally. "We've always liked it here at The Palacio haven't we?" He was quickly jovial, busy, pushing idly at silverware, getting up, his chair scraping. She didn't answer him. She took a sip of water.

"Oho. I see," he said, eyebrows up, smiling, coming around to her chair. "No jiggle-jiggle-jaggle. None?”

She got together her sweater, her handbag, taking her time.

"What do you think I am," she said. 